\title{
Effets de températures d'incubation légèrement supérieures ou inférieures à la normale sur la mortalité embryonnaire, les performances et l'état du plumage après l'éclosion
}

\author{
P Mérat, G Coquerelle
}

avec la collaboration technique de $\mathrm{A}$ Boscher

INRA, laboratoire de Génétique Factorielle, Centre de Recherches de Jouy-en-Josas, 78352 Jouy-en-Josas Cedex

(Reçu le 14 décembre 1990; accepté le 18 janvier 1991)

\begin{abstract}
Résumé - Des œuís fertiles pondus par les mêmes reproductrices ont été incubés soit à une température légèrement supérieure à la normale $\left(38,6^{\circ} \mathrm{C}\right)$ à partir du $7^{\theta}$ jour d'incubation, soit à une température de $36,8^{\circ} \mathrm{C}\left(1^{r \theta}\right.$ série) ou à une température unormale" de $37,7^{\circ} \mathrm{C}\left(2^{\theta}\right.$ série). Dans les 2 séries, les poules issues des œufs incubés à la température la plus élevée avaient un poids vif inférieur jusqu'à l'âge adulte (respectivement de 4,5 et $6,5 \%$ à 10 mois dans la $1^{\text {re }}$ et la $2^{\theta}$ série), leur emplumement était légèrement plus précoce, et les zones déplumées après 6 mois de production en cages de ponte, notées dans la seconde série, y étaient moins fréquentes et d'extension plus limitée. Le taux d'éclosion et les caractéristiques de ponte ne différaient pas en fonction de la température d'incubation.
\end{abstract}

poule / incubation / température / performance / emplumement

Summary - Effects of slightly higher or lower than normal incubation temperatures on embryonic mortality, post-hatching performances and feathering. Fertile eggs laid by the same breeding hens were incubated at a slightly higher than normal temperature $\left(38.6^{\circ} \mathrm{C}\right)$ from the 7 th $d$ of incubation, compared to a temperature of $36.8^{\circ} \mathrm{C}$ (1st series) or to a temperature of $37.7^{\circ} \mathrm{C}$ (2nd series). In both cases, females hatched from eggs incubated at the higher temperature had a moderately inferior body weight till adult age (by 4.5 and $6.5 \%$ respectively at 10 months in the 1st and 2nd series), feathered slightly earlier, and had less frequent and more limited bare areas in their plumage after 6 months' production in laying cages, as recorded in the 2nd series of comparisons. The hatching rate and laying traits were not affected by the incubation temperature.

domestic fowl / incubation / temperature / performances / feathering 


\section{INTRODUCTION}

L'influence de la température d'incubation ou du degré hygrométrique sur le taux d'éclosion a fait l'objet de nombreuses études (revues par Kosin, 1964, Lundy, 1969; Romanoff et Romanoff, 1972).

Relativement au développement et aux performances après l'éclosion, l'incidence d'une hypothermie de durée limitée appliquée à l'embryon a été recherché par Moreng et Bryant (1954), cités par Kosin (1964), par Buckland (1969, 1970), Buckland et Hill (1970), Shaver et Moreng (1975). Des conséquences variables sur la croissance sont notés par Moreng et Bryant (1954). Buckland (1970) et Buckland et Hill (1970) trouvent des effets contraires suivant que l'élevage a lieu en éclairage intermittent ou non. Michels et al (1974) examinent les conséquences sur la viabilité et la croissance ultérieure de 2 températures différentes d'incubation $(36,8$ et $37,8^{\circ} \mathrm{C}$ ). La plus faible température allonge la durée du développement embryonnaire, augmente la viabilité des jeunes jusqu'à $14 \mathrm{j}$ d'âge et le poids des mâles à 12 semaines. Michels et al (1980) obtiennent d'autre part une ponte abaissée pour des poules issues d'œufs incubés à une température inférieure à la normale.

Le présent travail apporte des résultats sur l'influence prolongée de 2 températures différentes d'incubation, en particulier sur la croissance pondérale et l'état du plumage.

\section{MATÉRIEL ET MÉTHODES}

\section{Séries et conditions expérimentales}

\section{$1^{\text {re }}$ série}

Une comparaison faite en octobre 1970 et mars 1972 porte sur des ceufs pedigree issus de notre troupeau. Tous les ceufs, conservés au maximum une semaine à $13{ }^{\circ} \mathrm{C}$ avant la mise en incubation, étaient incubés en même temps jusqu'au $6^{\circ} \mathrm{j}$ inclus a $37,7^{\circ} \mathrm{C}$. Du $7^{\circ}$ au $17^{\circ} \mathrm{j}$ d'incubation inclus, les œufs de chaque poule étaient répartis par moitié, soit à $38,6{ }^{\circ} \mathrm{C}$ ("surchauffe"), soit à $36,8^{\circ} \mathrm{C}$ ("sous-chauffe"). Les cufs des 2 groupes étaient mis dans le même éclosoir au $18^{\circ} \mathrm{j}$ d'incubation à $37,7^{\circ} \mathrm{C}$. Les conditions autres que la température après le $6^{\theta} \mathrm{j}$ d'incubation étaient aussi identiques que possible dans les lots comparés (même type d'appareil Bekoto à ventilation dynamique, $5 \mathrm{re}$ tournements par $24 \mathrm{~h}$, degré hygrométrique voisin de $50 \%$ puis $60 \%$ à l'éclosion). Pendant la période expérimentale, des relevés de température dans le lot "surchauffe" ont montré rarement des extrêmes de $38,3^{\circ} \mathrm{C}$ et $38,9^{\circ} \mathrm{C}$, la moyenne étant voisine de la valeur prévue.

Les poussins éclos des familles les plus nombreuses étaient gardés, en nombre égal pour les groupes soumis aux 2 températures d'incubation. Ces poussins étaient élevés tous ensemble, les mâles jusqu'après 8 semaines d'âge, les femelles jusqu'à 10 mois, au sol puis en cages individuelles depuis 17 semaines d'âge à partir de 1972. Les animaux jusqu'à 17 semaines recevaient l'éclairage du jour naturel; ce dernier était supplémenté ensuite jusqu'à une durée journalière de $14 \mathrm{~h}$ par un éclairage artificiel.

\section{$2^{\mathbf{e}}$ série}

En 1977,1978 et 1980 , une comparaison similaire a porté sur les œufs de mêmes poules, incubés entre le $7^{\theta}$ et le $17^{\theta} \mathrm{j}$ de la vie embryonnaire, soit à $38,6{ }^{\circ} \mathrm{C}$ ("surchauffe"), soit à $37,7^{\circ} \mathrm{C}$ (régime considéré comme "normal"). De même que pour la première série, une partie des poussins femelles éclos issus de chaque lot expérimental ont été comparées pour diverses variables.

\section{Variables mesurées}

Les variables mesurées dans chaque série sont indiquées dans les tableaux I et II. Les pourcentages d'éclosion étaient rapportés aux œufs trouvés embryonnés par mirage au $5^{\Theta} \mathrm{j}$ d'incuba- 
tion. Le poids des poussins était mesuré le jour de l'éclosion et rapporté au poids de l'œuf avant mise en incubation. L'emplumement à 8 semaines était évalué par le nombre de rectrices remplacées à cet âge. Le poids moyen des œufs de chaque poule était basé sur la ponte de 2 semaines avant l'âge de 10 mois, et les autres critères de qualité de l'œuf à partir de 2 œufs par poule au même age. Les poules "déplumées" étaient notées à 10 mois dans la seconde série par une échelle visuelle, allant de 0 à 3 (0 = plumage intact, 3 = larges zones déplumées). En 1980, une mesure individuelle de la consommation alimentaire et de la masse d'œufs sur une période de 4 semaines permettait d'obtenir l'indice de consommation pour la ponte (quantité d'aliment consommé/masse d'œufs).

\section{Analyses statistiques}

Le pourcentage de mortalité embryonnaire était comparé par une analyse $\left(\chi^{2}\right)$ tenant compte de l'effet "traitement" et "année" dans chacune des 2 séries expérimentales.

Dans chaque série également, chaque variable enregistrée après l'éclosion était comparée sur des couples de frères ou sœurs, l'un issu d'un cuf incubé en "surchauffe", l'autre issu d'un œuf incubé en "sous-chauffe" ou en température normale de 1977 à 1980. Les moyennes sont comparées par un test de Student-Fisher (méthode des couples), sauf pour l'emplumement à 8 semaines (variable discontinue) et le diamètre des tarses (faible précision de la mesure) pour lesquels un $\chi^{2}$ à 1 degré de liberté compare le nombre de différences en faveur du lot "surchauffe" au nombre de différences de signe contraire.

\section{RÉSULTATS}

La durée d'incubation n'a pas été mesurée; elle était visiblement raccourcie dans les lots "Surchauffe", et allongée dans les lots "sous-chauffe".

Les pourcentages d'éclosion rapportés aux œufs embryonnés obtenus dans cha- que traitement sont contenus respectivement dans les tableaux I et II pour les 2 séries expérimentales. Les œufs infertiles (notés "clairs" par observation visuelle au mirage) représentaient au total $5,1 \%$ des œufs incubés dans la première série et $8,9 \%$ dans la seconde.

Les performances après l'éclosion selon le traitement figurent également aux tableaux I et II pour les 2 séries expérimentales respectivement.

La mortalité aux différents stades de la vie post-embryonnaire était faible et voisine pour les 2 traitements; le détail n'en est pas présenté.

\section{DISCUSSION ET CONCLUSIONS}

\section{Pourcentages d'éclosion}

Entre les lots "surchauffe" et "souschauffe" incubés en même temps en 1970 et 1972 n'apparaît qu'une faible différence, non significative à l'intérieur de chaque année et au total. II en est de même des années 1977 à 1980 et de leur total. L'augmentation de la température d'incubation réalisée, volontairement modérée et limitée dans le temps, n'a pas eu d'incidence sensible sur la mortalité embryonnaire.

\section{Performances et mesures ultérieures}

Dans la comparaison "surchauffe - souschauffe", la température d'incubation la plus élevée se traduit par un plus faible poids du poussin éclos par rapport au poids de l'œuf et par un ralentissement modéré de la croissance ultérieure, poids à 8 semaines significativement moindre chez les femelles, différence non significative de même sens à 10 mois. L'emplume- 
Tableau I. Performances moyennes selon la température d'incubation. $1^{\text {re }}$ série (années 1970 et 1972 groupées).

\begin{tabular}{|c|c|c|c|c|c|}
\hline & $\begin{array}{c}\text { Nombre } \\
\text { de couples }\end{array}$ & $\begin{array}{r}\text { Valeur } \\
\text { "surchauffe" }\end{array}$ & $\begin{array}{l}\text { moyenne } \\
\text { «sous-chauffe» }\end{array}$ & Différence & Signification $^{2}$ \\
\hline $\begin{array}{l}\text { Poussins éclos/ } \\
\text { œuis fertiles (\%) }\end{array}$ & 1 & 60,8 & 62,3 & $-1,5$ & NS \\
\hline $\begin{array}{l}\text { Poids poussin/ } \\
\text { poids œufs (\%) }\end{array}$ & 93 & 65,3 & 68,0 & $-2,7$ & $\star \star \star *$ \\
\hline $\begin{array}{l}\text { Poids à } \\
8 \text { semaines } q(g)\end{array}$ & 42 & 770 & 837 & -67 & $* * *$ \\
\hline $\begin{array}{l}\text { Emplumement } 8 \text { semaines } \\
\text { (sexes groupés) }\end{array}$ & 63 & 5,81 & 5,38 & $+0,43$ & ** \\
\hline $\begin{array}{l}\text { Nombre d'œufs } \\
\text { jusqu'à } 10 \text { mois }\end{array}$ & 24 & 87,8 & 70,7 & $+17,1$ & $\star *$ \\
\hline Âge au $1^{\text {er }} œ u f(j)$ & 24 & 160,3 & 164,7 & $-4,4$ & NS \\
\hline $\begin{array}{l}\text { Poids moyen } \\
\text { des œufs (g) }\end{array}$ & 15 & 50,5 & 51,5 & $-1,0$ & NS \\
\hline $\begin{array}{l}\text { Hauteur } \\
\text { albumen }(0,1 \mathrm{~mm})\end{array}$ & 15 & 63,1 & 65,4 & $-2,3$ & NS \\
\hline $\begin{array}{l}\text { Épaisseur } \\
\text { coquille }(0,01 \mathrm{~mm})\end{array}$ & 15 & 37,5 & 38,6 & $-1,1$ & NS \\
\hline $\begin{array}{l}\text { Poids des } 9 \text { à } \\
10 \text { mois }(g)\end{array}$ & 24 & 2372 & 2484 & -92 & NS \\
\hline
\end{tabular}

1 Respectivement 563 et 571 œufs fertiles au total pour les 2 traitements; ${ }^{2 *},{ }^{* *},{ }^{* *}$ : respectivement $P<0,05 ; P<$ 0,$01 ; P<0,001$.

ment à 8 semaines est légèrement plus précoce dans le lot "surchauffe». Enfin, la première série suggérait un nombre d'œufs pondus supérieur pour ce même lot.

La série de comparaisons «surchauffe - température normale" de 1977 à 1980, sur des effectifs plus importants, montre comme la première série une tendance à une réduction du poids corporel consécutive à une température plus élevée d'incubation; cette réduction persiste à l'âge de
17 semaines (âge auquel le poids n'avait pas été mesuré auparavant), est significative à 10 mois et se répercute sur le poids moyen des œufs. En pourcentage, la réduction du poids du poussin était voisine de $4 \%$, celles concernant le poids à 8 semaines et le poids à 10 mois respectivement de 8,0 et $3,7 \%$ dans la première série; dans la seconde, le poids à 8 semaines et le poids adulte sont diminués respectivement de 6,0 et $6,4 \%$ et le poids de l'cuf de 2,6\% par l'augmentation de la 
Tableau II. Performances moyennes selon la température d'incubation : $2^{\circ}$ série (années 1977, 1978 et 1980 groupées).

\begin{tabular}{|c|c|c|c|c|c|}
\hline & $\begin{array}{c}\text { Nombre } \\
\text { de couples }\end{array}$ & $\begin{array}{r}\text { Valeur } \\
\text { "surchauffe" }\end{array}$ & $\begin{array}{l}\text { moyenne } \\
\text { témoin }\end{array}$ & Différence & Signification \\
\hline $\begin{array}{l}\text { Poussins éclos/ } \\
\text { œufs fertiles (\%) }\end{array}$ & 1 & 81,2 & 80,1 & $+1,1$ & NS \\
\hline $\begin{array}{l}\text { Poids à } \\
8 \text { semaines } q \text { (g) }\end{array}$ & 261 & 630 & 670 & -40 & $* * *$ \\
\hline $\begin{array}{l}\text { Poids à } \\
17 \text { semaines } \& \text { (g) }\end{array}$ & 259 & 1476 & 1543 & -67 & $* * *$ \\
\hline $\begin{array}{l}\text { Emplumement à } \\
8 \text { semaines } ₹\end{array}$ & 255 & 6,16 & 6,01 & $+0,15$ & * \\
\hline $\begin{array}{l}\text { Âge au } \\
f^{\theta r} œ u f(j)\end{array}$ & 293 & 149,0 & 149,2 & $-0,2$ & NS \\
\hline $\begin{array}{l}\text { Nombre d'œufs } \\
\text { jusqu'à } 10 \text { mois }\end{array}$ & 293 & 99,9 & 100,8 & $-0,9$ & NS \\
\hline $\begin{array}{l}\text { Poids moyen } \\
\text { des œufs }(g)\end{array}$ & 254 & 52,3 & 53,7 & $-1,4$ & NS \\
\hline $\begin{array}{l}\text { Hauteur albumen } \\
(0,1 \mathrm{~mm})\end{array}$ & 175 & 58,0 & 59,0 & $-1,0$ & NS \\
\hline $\begin{array}{l}\text { Épaisseur coquille } \\
(0,01 \mathrm{~mm})\end{array}$ & 174 & 37,4 & 37,5 & $-0,1$ & NS \\
\hline $\begin{array}{l}\text { Poids à } 10 \text { mois } \\
\text { \& (g) }\end{array}$ & 293 & 2016 & 2155 & -139 & *** \\
\hline $\begin{array}{l}\text { Indice de consommation } \\
\text { (g aliment/g œufs) }^{2}\end{array}$ & 76 & 2,95 & 2,81 & $+0,14$ & NS \\
\hline $\begin{array}{l}\text { Poules } \\
\text { "déplumées" \% }\end{array}$ & 293 & 56,8 & 71,0 & & *** \\
\hline $\begin{array}{l}\text { Note moyenne } \\
\text { "déplumées" }\end{array}$ & 293 & 0,14 & 0,75 & & $\star * * *$ \\
\hline
\end{tabular}

${ }^{1}$ Respectivement 2071 et 2221 cufs fertiles pour les 2 traitements; ${ }^{2}$ mesuré seulement en 1980 sur 4 semaines; *, **, "** : respectivement $P<0,05 ; P<0,01 ; P<0,001$.

température d'incubation. Par contre, on ne retrouve pas dans cette seconde série de différence entre traitements pour le nombre d'œufs. D'autre part, l'effet réducteur plus important d'une température d'incubation plus élevée sur le poids corporel adulte que sur le poids des œufs suggère la possibilité d'une répercussion favorable sur l'indice de consommation; cependant l'effet du traitement sur ce dernier n'est pas significatif sur les données limitées présentées ici. 
On retrouve une faible différence de précocité d'emplumement en faveur du lot "surchauffe" de 1977 à 1980. D'autre part, les poules ayant été soumises à une température plus élevée durant la vie embryonnaire sont nettement avantagées pour l'état du plumage à l'âge de 10 mois en cages de ponte.

\section{CONCLUSIONS}

Comme il a été dit plus haut, nous avons voulu réaliser des différences limitées de la température d'incubation, n'affectant que peu ou pas le taux d'éclosion, mais susceptibles d'avoir certains effets prolongés au cours de la vie post-embryonnaire.

La réduction de poids du poussin éclos par une augmentation de la température d'incubation peut être rapportée en partie à la perte d'eau accrue par évaporation au cours de l'incubation, en partie aussi à une éclosion plus précoce laissant un délai plus long pour une perte de poids avant la pesée. Quant à la croissance ultérieure, nos résultats vont dans le même sens que ceux obtenus par Michels et al (1974). Ils montrent d'autre part qu'il n'y a pas d'atténuation au cours du temps de l'effet dépressif de la température la plus élevée d'incubation sur le poids.

On ne peut encore dire, par ailleurs, s'il y a un lien entre les 2 effets significatifs concernant le plumage. L'effet d'amélioration de l'état du plumage en cages de ponte après environ 6 mois de production par une "surchauffe" en incubation est intéressant dans la mesure où un mauvais emplumement en fin de ponte peut contribuer à une détérioration de l'efficacité alimentaire (Pym, 1990).

\section{RÉFÉRENCES}

Buckland RB (1969) Effect of cold stressing chick embryos on hatchability and posthatching body weight. Can J Anim Sci 49, 132-134

Buckland RB (1970) Effect of cold stressing chicken embryos and preincubation storage on hatchability, post-hatching body weight, mortality and sex ratios. Can J Anim Sci 50, 243-253

Buckland RB, Hill AT (1970) Effects of continuous and intermittent light on broilers cold stressed as embryos. Can J Anim Sci 50, 735-738

Kosin IL (1964) Recent research trends in hatchability. Related problems of the domestic fowl. World's Poult Sci J 20, 254-268

Lundy $H$ (1969) A review of the effect of temperature, humidity, turning and gaseous environment in the incubator on the hatchability of the hen's egg. In: Fertility and Hatchability of the Hen's Egg (TC Carter, BM Freeman, eds) BEMB Symposium $n^{\circ}$ 5, $143-176$

Michels H, Decuypere E, Geers R (1980) Production and physiological criteria in laying RIR hens in relation to prenatal and postnatal environmental temperature. In: Energy Metabolism. Studies in the Agricultural and Food Sciences. Butterworths, London, 37-125

Michels H, Geers R, Muambi SB (1974) The effect of incubation temperature on pre- and post-hatching development in chicken. Brit Poult Sci 15, 517-524

Moreng RE, Bryant RL (1954) Effects of subfreezing temperature exposure on the chicken embryo. 2. Hatchability, chick weight and survival to 6 weeks. Poult Sci 33, 987-991

Pym RAE (1990) Nutritional genetics. In: Poultry Breeding and Genetics (Crawford RD, ed) Elsevier, Amsterdam, 847-876

Romanoff AL, Romanoff AJ (1972) Pathogenesis of the avian embryo. J Wiley \& Sons, NY

Shaver MF, Moreng RE (1975) Hypothermal stress resistance in the domestic fowl. 4. Adaptive response in chick body and gland weights. Egypt J Genet Cytol 4, 41-56 